Jurnal Ilmu Budaya, Vol. 18, No. 2 Februari Tahun 2022

\title{
RONGGENG DUKUH PARUK DAN PEREMPUAN KEMBANG JEPUN (KAJIAN SASTRA BANDING)
}

\author{
Inung Setyami \\ Universitas Borneo Tarakan \\ inungsetyami@borneo.ac.id
}

\begin{abstract}
This study aims to discribe the form of subordination experienced by geisha in the novel Perempuan Kembang Jepun by Lan Fang and Ronggeng in the novel Ronggeng Dukuh Paruk by Ahmad Tohari. The data source of this research used two novels, namely the novel Perempauan Kembang Jepun (PKJ) by Lan Fang and the novel Ronggeng Dukuh Paruk (RDP) by Ahmad Tohari. The results showed that 1) novel $P K J$ by Lan Fang and novel RDP by Ahmad Tohar, the central character is a woman who works as a dancer. Ronggeng dancers are included in RDP, while geisha are inclued in PKJ; 2) Both novels present male characters related to the geisha and ronggeng professions; 3) There are similarities in ideas, namely women in both PKJ and RDP novels experience subordination to male power that has been socially constructed; 4) Biologically, dancers in PKL and RDP have the idea of eliminating the absolute nature of women (pregnancy, giving birth); 4) There are absolute requirements for prospective dancers, namely mizuage (virginity auction) for geisha candidates and "bukak klambu" (virginity contest) for ronggeng candidates.
\end{abstract}

Keyword: ronggeng, geisha, subordination, women

\section{Pendahuluan}

Melalui sastra, pegarang dapat mengungkapkan berbagai problematika manusia. Sastra dapat melukiskan penderitaan-penderitaan manusia dan perjuangan untuk melepaskan diri dari penderitaan tersebut. Dengan karya sastra, seorang pengarang mampu menampilkan nilainilai yang lebih tinggi dalam menafsirkan makna hidup. Oleh karena itu, sastra mengemban tugas penting dalam kehidupan (Esten, 1990: 8).

Karya sastra yang berhasil tidak hanya cukup dilihat dari segi estetik bahasanya, melainkan bagaimana kemampuan karya sastra tersebut dalam memahami persoalan kehidupan yang kompleks (sosial, 
Jurnal Ilmu Budaya, Vol. 18, No. 2 Februari Tahun 2022

politik, ekonomi, agama, budaya, dsb).

Diantara berbagai tema permasalahan kehidupan yang ada, salah satu yang menarik dan hingga kini semarak diperbincangkan adalah persoalan perempuan.

Ideologi yang menyatakan bahwa kedudukan laki-laki lebih tinggi daripada kedudukan perempuan masih mengakar dalam kehidupan masyarakat (Bhasin dan Khan, 1993: 25). Lebih lanjut, Bhasin dan Khan menyatakan bahwa ideologi yang berkembang dalam sistem sosial masyarakat tersebut akan berimbas secara langsung terhadap upaya pengekangan yang dilakukan laki-laki terhadap gerak sosial perempuan yang dinilai wajar. Pengekangan tersebut dapat berupa pandangan-pandangan yang menyatakan bahwa perempuan harus dikontrol oleh laki-laki dan perempuan adalah bagian dari milik laki-laki.

Kondisi tersebut menghadapkan perempuan pada suatu sistem, yaitu sistem dominasi dan superioritas laki-laki serta sistem kontrol terhadap perempuan.

Kekuasaan laki-laki terhadap perempuan inilah yang kemudian dimaknai sebagai sistem patriarki. Menurut Bhasin (1996: 5), sistem patriarki telah memberikan kontribusi dalam pembentukan sebuah anggapan bahwa laki-laki berhak mengontrol perempuan, di antaranya berupa kontrol terhadap daya produktif atau tenaga kerja perempuan, kontrol terhadap reproduksi perempuan, kontrol terhadap seksualitas perempuan, dan kontrol terhadap gerak serta kebebasan perempuan.

Selanjutnya, hal-hal yang berkaitan dengan ketertindasan perempuan ini dapat ditemui di dalam karya sastra. Pengarang sastra dalam dunia kesusasteraan Indonesia dari dulu hingga kini telah menunjukkan perhatian yang serius terhadap karya sastra yang mengusung ideologi feminisme. Pada umumnya karya sastra dengan ideologi feminisme tersebut lahir dari para pengarang karena perempuan dianggap telah dirugikan dan dinomorduakan oleh 
pihak laki-laki, baik itu dalam bidang ekonomi, sosial, pendidikan dan sebagainya. Bahkan, feminisme dalam penelitian sastra dianggap sebagai gerakan kesadaran terhadap pengabaian dan eksploitasi perempuan dalam masyarakat seperti tercermin dalam karya sastra. Salah satu teori feminis yang berkembang saat ini adalah feminisme sosialis.

Menurut Bhasin (1996: 39), feminisme sosialis menyatakan bahwa perempuan dapat dilihat sebagai penghuni kelas ekonomi dalam pandangan Marx dan "kelas seks". Dengan demikian, perempuan menampilkan pelayanan berharga bagi kapitalisme, baik sebagai pekerja maupun istri yang tidak menerima upah atas kerja domestik mereka. Selanjutnya, Bhasin menyatakan bahwa sistem patriarki dan kapitalisme yang telah mengakar dalam sistem sosial masyarakat merupakan faktor utama yang mensubordinasikan keberadaan perempuan. Hal ini dapat ditemui pada kesewenang-wenangan laki-laki dalam mengontrol aspekaspek kehidupan perempuan.

Berdasarkan latar belakang di atas, perlu dilakukan kajian yang berhubungan dengan feminisme yang terefleksi dalam novel-novel Indonesia. Kajian berperspektif feminis ini diharapkan mampu menjawab berbagai kondisi hidup perempuan yang merugi akibat gender. Selanjutnya, untuk membatasi penelitian, dipilih dua novel sebagai sumber data, yaitu novel Perempuan Kembang Jepun karya Lan Fang dan novel Ronggeng Dukuh Paruk karya Ahmad Tohari dalam kaitannya dengan feminis sosialis, khususnya subordinasi perempuan.

Novel Perempuan Kembang Jepun (PKJ) karya Lan Fang terbit pertama tahun 2006. Novel ini menceritakan sosok geisha bernama Matsumi, seorang perempuan berkewarganegaraan Jepang. Matsumi adalah seorang geisha asli Jepang yang tinggal di Surabaya dikarenakan harus melayani Shosho Kobayashi, seorang mayor jenderal dari Jepang yang 
sedang bertugas di Surabaya. Matsumi harus berhenti menjadi geisha karena menyalahi aturan ke-geisa-annya, yakni melibatkan perasaan dan menikah dengan seorang laki-laki bernama Sujono. Lepas dari dunia kegeisha-an, kehidupannya menjadi sangat menyedihkan karena ternyata Sujono tak mampu mencukupi kebutuhan rumah tangga mereka.

Sementara itu, novel Ronggeng Dukuh Paruk menceritakan ronggeng yang merupakan ciri khas Dukuh Paruk. Srintil adalah pewaris ronggeng setelah diyakini kemasukan indang ronggeng. Ia mengemban tugas sebagai "kembang Dukuh Paruk" atau simbol nafas pedukuhan kecil itu dengan memerankan seorang ronggeng sebagai amanat Ki Secamenggala (sesepuh di Dukuh Paruk yang terus dipuja hingga akhir hayatnya). Pada awalnya Srintil bangga dengan statusnya sebagai ronggeng, namun ia merasa sisi-sisi keperempuanannya menolak sebagai ronggeng. Ia harus menari. Ia harus melayani banyak lakilaki yang tidak ia cintai. Ia menjadi perempuan milik banyak laki-laki (sesuatu yang tidak ia inginkan, karena ia hanya mencintai Rasus). Pada akhirnya, Srintil pun menyalahi sisisisi ke-ronggeng-annya, yaitu jatuh cinta dengan Rasus. Hal ini membuat Srintil lengser dari dunia peronggengan, bahkan kisahnya menjadi sangat tragis karena ia menjadi gila setelah berulangkali menuai rasa kecewa terhadap lelaki. Berdasarkan pembandingan dua buah novel tersebut, maka di antara keduanya akan terdapat persamaan dan perbedaan perlakuan terhadap gagasan.

Novel Kembang Jepun karya Lan Fang dan novel Ronggeng Dukuh Paruk karya Ahmad Tohari dapat dibandingkan keduanya dengan metode sastra bandingan. Sastra bandingan merupakan sastra yang bersifat antar disiplin. Hal ini berbeda dengan perbandingan sastra yang hanya memperbandingkan sastra dengan sastra tanpa berpijak pada teori. Kesusasteraan Bandingan telah banyak diperdebatkan pada abad ke 19. Dengan demikian tampak jelas 
Jurnal Ilmu Budaya, Vol. 18, No. 2 Februari Tahun 2022

bahwa kesusasteraan bandingan telah melalui sejarah yang panjang. Perjalanan ini bermula di Sorbone Perancis dan lebih dikenal dengan "Mazhab Perancis" dengan tokoh penggeraknya $\mathrm{H}$. M Possnet, Joseph Texte, dan Paul Van Tieghem. Mazhab ini mengemukakan bahwa kajian kesusteraan bandingan adalah kajian penyilangan karya sastra dari satu negara saja. Perkembangan selanjutnya, munculnya "Mazhab Amerika" yang memilki pandangan lebih luas (Aziz, 2001: 1-6).

Sastra banding menurut Remak adalah kajian sastra di luar batas-batas negara dan kajian hubungan di antara sastra dan bidang ilmu lainnya (ekonomi, sejarah, sosial, politik, agama, filsafat, psikologi, dan seni). Dari uraian tersebut dapat dikatakan bahwa sastra bandingan adalah membandingkan sastra sebuah negara atau dengan negara lain dan membandingkannya dengan bidang lain sebagai ungkapan peleburan seluruh aspek kehidupan.
Sementara itu, Robert J. Clements menyatakan bahwa pendekatan karya sastra dalam studi bandingan mencakup lima unsur penekanan, yaitu: (1) tema, (2) genre/bentuk, (3) aliran/zaman, (4) hubungan antara sastra dan seni lain, dan (5) keterkaitan sastra untuk menjelaskan perkembangan teori dan kritik sastra.

Permasalahan dalam novel Perempuan Kembang Jepun karya Lan Fang dan Ronggeng Dukuh Paruk karya Ahmad Tohari adalah bagaimanakah wujud subordinasi yang dialami geisha dalam perspektif feminisme sosialis pada novel Perempuan Kembang Jepun Lan Fang dan Ronggeng dalam novel Ronggeng Dukuh Paruk karya Ahmad Tohari.

Penelitian ini merupakan penelitian deskriptif kualitatif. Sumber data penelitian menggunakan dua novel. Novel pertama, yaitu Perempuan Kembang Jepun (PKJ) karya Lan Fang dengan tebal buku 288 halaman. Novel ini diterbitkan pertama kali pada Oktober 2006 oleh PT. 
Jurnal Ilmu Budaya, Vol. 18, No. 2 Februari Tahun 2022

Gramedia Pustaka Utama. Novel kedua berjudul Ronggeng Dukuh Paruk (RDP) karya Ahmad Tohari, cetakan kelima (2009) dan diterbitkan oleh PT Gramedia Pustaka Utama. Pengumpulan data dilakukan dengan teknik baca catat, yaitu pembacaan disertai pencatatan dengan cermat dan teliti keseluruhan novel. Langkahlangkah pengumpulan data meliputi (1) membaca secara cermat dan keseluruhan novel $P K J$ dan $R D P$; (2) mengidentifikasi dan menandai bagian-bagian tertentu pada novel $P K J$ dan $R D P$ yang mengandung data yang diperlukan sesuai dengan permasalahan dalam penelitian; (3) mencatat hasil identifikasi data yang berupa kutipan-kutipan; (4) melakukan interpretasi atau penafsiran terhadap data yang telah terkumpul; dan (5) mendeskripsikan semua data yang diperoleh.

\section{Hasil dan Pembahasan}

Pada pembahasan ini akan dilakukan perbandingan mengenai gagasan fenomena tokoh penari yang terdapat dalam novel Perempuan Kembang Jepun (PKJ) karya Lan Fang dan novel Ronggeng Dukuh Paruk (RDP) karya Ahmad Tohari. Perbandingan ini dilakukan dengan tujuan untuk mengetahui perbedaan dan persamaan penggambaran fenomena penari yang terdapat pada kedua novel tersebut. Dalam $P K J$ dan $R D P$ terdapat perbedaan dalam mengungkapkan istilah seorang penari. Hal ini dapat dicermati pada kutipan di bawah ini.

"Penagih birahi yang ditampilkan oleh seorang Ronggeng yang sebenarnya juga diperbuat oleh Srintil saat itu, lenggok lehernya, lirik matanya, bahkan cara Srintil mengoyangkan pundak akan memukau laki-laki dewasa manapun yang melihatnya. Seorang gadis kencur Srintil telah mampu meniru dengan baiknya gaya seorang ronggeng." (Tohari, 2009: 13)

$\quad$ "Kau juga cantik. Kelak kau
akan menjadi geisha tercantik.
Lihat...kulitmu bersih, wajahmu
seperti telur, matamu tidak sipit seperti
kebanyakan orang, bibirmu kecil dan
indah, hmmm lalu pinggangmu kecil,
pinggulmu bulat dan dadamu tumbuh
penuh." (Fang, 2006: 102-103)


Jurnal Ilmu Budaya, Vol. 18, No. 2 Februari Tahun 2022

Kedua kutipan di atas laki-laki dalam sehari. Aku bisa memperlihatkan perbedaan istilah dalam menyebut perempuan yang berprofesi sebagai penari. Novel $P K J$ menggunakan istilah geisha, sedangkan novel $R D P$ menggunakan istilah ronggeng. geisha dan ronggeng merupakan seni dari dua budaya yang berbeda. Geisha merupakan produk budaya Jepang dan hanya ada dan dikenal di Jepang. Jika pun ada perempuan yang berprofesi sejenis dengan profesi geisha yang ada di luar Jepang itu bukanlah geisha, namun sebagai perempuan penghibur atau sering disebut jughun ianfu (perempuan pemuas nafsu) dan pelacur. Hal ini terlihat pada kutipan di bawah ini.

"Geisha hanya ada di jepang. Di sini tidak ada geisha."

"Lalu?" aku tidak mengerti.

"Mereka perempuan penghibur"

Aku masih tidak mengerti. (Fang, 2006: 96)

"Mereka bukan geisha..." desisku menahan kesedihan sendiri.

Setidaknya aku juga perempuan. Aku juga perempuan yang melayani laki-laki untuk mencapai kepuasan tertinggi, tetapi aku tidak sekedar mengangkang untuk dimasuki puluhan menyanyi, menari, bermain shamisen, memandikan laki-laki di ofuro. Aku perempuan yang bercinta di dalam seni.

"Lalu mereka apa?" Tanyaku sedih dan pilu

"Kami menyebutnya jughun ianfu...perempuan pemuas nafsu.

"Kenapa harus seperti itu?"

"Karena semua tentara butuh perempuan." (Fang, 2006: 115)

Baik perempuan penghibur, jughun ianfu, atau geisha, walaupun mereka memiliki kedudukan yang berbeda namun pada dasarnya mereka memiliki profesi yang sama yakni menghibur dan memberikan pelayanan seksual kepada laki-laki di luar pernikahan yang kemudian mendapat imbalan berupa uang. Perbedaannya, yaitu seorang geisha dituntut memilki kecakapan dalam melakukan tugasnya, yakni memiliki berbagai kerajinan dan kesenian tinggi dalam melayani, misalnya menyanyi, menari, bermain shamisen (alat musik jepang), dan memandikan laki-laki di ofuro (bak mandi dengan air hangat).

Johnston (2005: 37-40) menyatakan bahwa geisha yang paling rendah adalah geisha yang hanya tahu 
sedikit saja tentang keterampilan dan hanya dapat memainkan beberapa baris shamisen (alat musik tradisional Jepang) dan sedikit menyanyi. Geisha yang masuk dalam kelompok ini hanya memiliki sedikit kelebihan dibandingkan dengan pelacur. Selanjutnya, menurut Johnston, sebagian geisha hidup dan bekerja di tempat-tempat peristirahatan sumber air. Mereka melayani makanan dan minuman para pelanggan, menyanyi, menari, dan seringkali-meskipun tidak selalu—memberikan kesenangan seksual.

Calon geisha dan ronggeng menjalani pelatihan terlebih dahulu sebelum dikukuhkan menjadi seorang ronggeng dan geisha. Walaupun geisha menempuh pelatihan ke-geisha-an dan ronggeng menempuh pelatihan keronggengannya, namun demikian pelatihan yang mereka jalani tidaklah sama. Ronggeng dilatih oleh seorang dukun ronggeng. Dalam $R D P$, tampak bahwa Srintil (calon ronggeng) harus diserahkan dan tinggal bersama dukun ronggeng selama akan menjadi ronggeng. Dukun ronggeng itu akan melatih wawasan calon ronggeng bagaimana menari dan melempar sampur. Selain itu, dukun ronggeng akan memberikan ajian pengasih (susuk) kepada calon ronggeng. Ajian pengasih ini berguna untuk memikat laki-laki yang kelak akan menonton pertunjukannya dan membuat ronngeng tersebut laris. Sementara itu, calon geisha memperoleh pendidikan bagaimana mengenakan yukata dan $o b i$, dan berdandan. Ada istilah untuk menyebut calon geisha, yaitu maiko. Sementara itu, tidak ada penyebutan istilah khusus untuk calon ronggeng. Hal ini tampak pada kutipan berikut

"Dan tentu sampean perlu memperhalus tarian Srintil. Cucuku tampaknya belum pintar melempar sampur. Nah, ada lagi yang penting masalah rangkap tentu saja. Itu urusanmu bukan?" Kertareja terkekeh. Dia merasa tidak perlu berkata apaapa. Rangkap yang dimaksud oleh Sakarya tentulah soal guna-guna, pekasih, sukuk dan tetek bengek lainnya". (Tohari, 2009: 16)

"Di Gion, aku hanya mendapatkan pelajaran bagaimana mengenakan yukata, obi, atau kimono tetapi Yuriko meberikan pelajaran 
bagaimana memadukan warna kimono dan obi sehingga menjadi paduan corak yang menarik. Di Gion aku juga mendapatkan pelajaran berdandan menyanggul rambut. Tetapi Yuriko memberiku banyak tusuk konde yang indah." (Fang, 2006: 103)

"Sebelum menjadi geisha kau disebut Maiko. Kau belajarlah baikbaik, karena menjadi geisha tidaklah mudah. Tidak hanya harus cantik tapi juga cerdas. Juga harus pandai menyenangkan laki-laki dan memberikan kepuasan yang sempurna..." (Fang, 2006: 102-103)

Selanjutnya terkait dengan penari dari dua budaya yang berbeda, yaitu geisha (Jepang) dan rongggeng (Indonesia), terdapat gagasan yang sama mengenai keperawanan (virginitas). Gagasan tersebut berupa syarat mutlak menjadi geisha atau ronggeng yaitu "melepas" keperawanan mereka kepada laki-laki yang sanggup membayar harga keperawanan tersebut dengan harta/harga tertinggi. Istilah "pelepasan" keperawanan perempuan dari kedua novel tersebut berbeda. Pada novel $P K J$, calon geisha harus menjalani Mizuaze yang berarti pelelangan keperawanan. Sementara itu, pada novel Ronggeng Dukuh Paruk, calon ronggeng harus menjalani Bukak Klambu (semacam sayembara keperawanan). Hal ini dapat dilihat pada kutipan berikut.

"Ketika usiaku mencapai empat belas tahun, aku menjadi geisha. Sebelumnya aku menjalani mizuage, yaitu proses melelang keperawananku kepada penawar dengan harga tertinggi. Waktu itu, menurut induk semangku, ada tiga orang kaya dan terpandang di Kyoto yang menawarku. Induk semangku membawa aku ke hadapan mereka, Mereka satu persatu melihatku telanjang bulat". (Fang, 2006: 104)

“ Dari orang-orang Dukuh Paruk pula aku tahu syarat terakhir yang harus dipenuhi oleh Srintil bernama bukak klambu. Berdiri bulu kudukku setelah mengetahui macam apa persyaratan itu. Bukak klambu adalah semacam sayembara, terbuka bagi laki-laki manapun. yang disayembarakan adalah keperawanan calon ronggeng. Laki-laki yang dapat menyerahkan sejumlah uang yang ditentukan oleh dukun ronggeng, berhak menikmati virginitas itu." (Tohari, 2009: 51)

Gagasan selanjutnya, yaitu gagasan mengenai alat reproduksi penari yang terdapat pada novel $P K J$ dan RDP. Gagasan mengenai alat reproduksi dalam $P K J$ memiliki 
kesamaan apabila dibandingkan pada $R D P$. Pada kedua novel tersebut, geisha dan ronggeng merupakan tokoh perempuan yang tidak memiliki hak untuk menggunakan alat reprodukinya. Dalam kedua novel tersebut, geisha dan ronggeng tidak diperbolehkan hamil, dan melahirkan anak. Padahal hamil, melahirkan, dan mengiginkan anak adalah kodrat perempuan, namun keinginan harus "terlupakan" hanya karena sebuah pandangan yang telah ditetapkan sebagai suatu keharusan. Berikut adalah kutipan mengenai hak reproduksi seorang geisha.

"Aku tahu, aku telah berbuat kesalahan terbesar."

"Apakah kau lupa bahwa kau geisha tercantik?! Tidak pernah seorang geisha hamil, melahirkan, dan mempunyai anak. Geisha adalah penghibur! Geisha harus selalu menjaga kecantikan wajah dan keindahan tubuh. Hamil, melahirkan, punya anak, akan membuat wajah dan tubuhmu yang indah menjadi rusak..." (Fang, 2006: 141)

\section{Kutipan}

tersebut

memperlihatkan dengan jelas bahwa geisha adalah perempuan yang tidak memiliki hak atas alat reproduksinya sendiri. Bahkan, seorang perempuan yang berprofesi menjadi geisha dilarang menggunakan haknya untuk menikah karena pernikahan dianggap menyalahi etika profesi geisha. Selain itu, geisha tidak boleh hamil dan melahirkan karena hamil dan melahirkan sangat dikhawatirkan dapat merusak kecantikan wajah dan keindahan tubuh seorang geisha. Jika sudah demikian (tubuh dan wajah rusak), seorang geisha dianggap tidak memiliki kesempurnaan dalam melakukan pelayanan terhadap lakilaki. Terkait dengan adanya subordinasi perempuan, kutipan di atas, (percakapan Hanada San dengan Matsumi) menunjukkan adanya pengontrolan biologis terhadap perempuan, yaitu kontrol terhadap fungsi alat reproduksi. Pengontrolan tersebut dilakukan secara ketat oleh Hanada San (majikan) walaupun Matsumi tak menghendaki hal itu terjadi pada dirinya. Singkatnya, Matsumi sebagai perempuan mendapat tekanan dari sistem kapitalis dan patriarki, hal inilah yang kemudian 
Jurnal Ilmu Budaya, Vol. 18, No. 2 Februari Tahun 2022

menghalanginya untuk mencapai

esensi keperempuanan.

Sementara itu, gagasan mengenai alat reproduksi dan kontrol biologis juga terlihat dalam $R D P$. Dalam RDP terdapat larangan untuk hamil bagi seorang perempuan yang berprofesi sebagai ronggeng. Bahkan larangan hamil ini bukan hanya sekedar larangan dalam bentuk peringatan saja, namun sudah menjadi sikap yang sangat keras yaitu dengan tindakan mematikan peranakan atau indung perempuan ronggeng yang dilakukan oleh dukun ronggeng. Dengan demikian, seorang yang menjadi ronggeng tidak akan hamil walau telah melakukan hubungan seksual. Hal ini adalah syarat mutlak seorang ronggeng. Jika melanggar syarat mutlak ini, karier seorang ronggeng akan berhenti dengan sendirinya. Selain permasalahan reproduksi dan kehamilan, pernikahan bagi seorang ronggeng tidaklah dianggap sebagai hal yang sakral, melainkan hal yang lucu.
Tidak mustahil, jika seorang perempuan_demikian juga Srintil si ronggeng_sangatlah mendamba menjadi perempuan sebagai ibu, yang mampu hamil, melahirkan, dan merawat anak. Namun demikian, keinginan Srintil itu hanyalah tinggal angan-angan yang menyakitkan lantaran dirinya telah menyadari bahwa ia sebagai perempuan tidak akan mampu mencapai anganangannya lantaran indung telurnya telah dimandulkan atas nama profesinya sebagai ronggeng. Sungguh tragis, hanya untuk mempertahankan kecantikan agar mampu menjadi penghibur lelaki, kodrat perempuan harus dikorbankan, seperti tampak pada kutipan berikut.

"Lucu. Seorang ronggeng berceloteh tentang perkawinan, tentang seorang bayi. Sebagai anak Dukuh Paruk sejati, aku langsung bisa mencurigainya. Aku tahu benar, perkawinan di Dukuh Paruk bukan barang muluk apalagi kudus, maka perempuan di sana tak perlu memujanya." (Tohari, 2009: 89)

"Aku menduga keras, bahwa Srintil mulai dihantui kesadaran bahwa Kertareja telah memijit hingga mati indung telurnya, peranakannya. Suami 
istri dukun ronggeng itu merasa perlu berbuat demikian sebab hukum Dukuh Paruk mengatakan karier seorang ronggeng akan terhenti sejak kehamilannya. Kukira Srintil mulai sadar bahwa kemandulannya adalah hantu mengerikan yang akan menjelang hari tua." (Tohari, 2009: 90)

Tokoh perempuan dalam kedua novel tersebut mendapat larangan jatuh cinta atau melibatkan perasaannya kepada laki-laki. Geisha dalam $P K J$ dan ronggeng dalam $R D P$ adalah seniwati penghibur lelaki yang tidak berhak melibatkan perasaannya kepada para lelaki. Bahkan, jika seorang ronggeng atau geisha memiliki perasaan terhadap lelaki, maka perasaan itu dianggap tidak wajar. Hal ini dapat dilihat pada kutipan berikut.

"Eh dengar! Pernahkah seorang ronggeng mabuk kepayang terhadap seorang lelaki? ," seorang perempuan yang bersama dua temannya sedang mencari kutu di bawah pohon nangka.

"Sepanjang yang kudengar tak ada cerita demikian." Jawab perempuan kedua

"Yang baku, seorang lelaki tergila-gila kepada ronggeng karena ronggeng memang dibuat untuk menarik hati laki-laki. Dia tidak boleh terikat kepada seorangpun. Lha, bagaimana kalau dia sendiri dimabuk cinta demikian." (Tohari, 2009: 115)
"Cinta?! Tidak pernah ada kata cinta dalam kamus hidup seorang geisha. Geisha adalah boneka porselen cantik yang tidak boleh retak. Cinta bukan saja membuat boneka porselen rusak, tapi hancur berkeping-keping!" (Fang, 2003: 142)

Yuriko pernah berkata, "Tugas seorang geisha hanyalah menghibur. Menyenangkan laki-laki. Memberi kepuasan sempurna. Bukan ikut terlibat secara perasaan. Berciuman dengan bibir hanya akan melibatkan perasaan. Biasanya sehabis menemani tamu minum sake, bercakap-cakap atau menyanyi, aku menawarinya mandi di ofuro. Tamuku akan berendam di bak dengan air hangat, lalu aku menggosok punggung dan dadanya dengan kain basah. Lebih tepat kalau kukatakan membelai...'(Fang, 2006: 131)

Demikian juga seorang geisha. Seorang geisha tidak berhak mengumbar perasaannya kepada lelaki. Geisha tidak diperbolehkan jatuh cinta terhadap seorang lelaki karena jatuh cinta hanya membuat seorang geisha tak mampu melakukan pekerjaannya dengan sempurna. Padahal perasaan jatuh cinta dan melibatkan perasaan adalah hal yang wajar bagi manusia, namun demi profesi, seorang perempuan harus 
Jurnal Ilmu Budaya, Vol. 18, No. 2 Februari Tahun 2022

mematikan perasaannya. Tugas geisha hanyalah melayani laki-laki. Sebagai seorang pelayan dengan tuntutan mampu memberi kepuasan merupakan suatu keadaan yang menunjukkan bahwa keberadaan perempuan (geisha) tersubordinasi oleh kaum laki-laki.

\section{Penutup}

Novel Perempuan Kemban Jepun $(P K J)$ karya Lan Fang maupun Ronggeng Dukuh Paruk (RDP) karya Ahmad Tohari, tokoh sentralnya adalah perempuan yang berprofesi sebagai penari. Penari ronggeng terdapat dalam $R D P$, sementara itu geisha terdapat dalam $P K J$. Kedua novel tersebut menghadirkan tokoh laki-laki yang berkaitan dengan profesi geisha dan ronggeng. Tokoh laki-laki yang dihadirkan dalam $P K J$, yaitu Hanada Shan (majikan geisha), dan Shoso Kobayasi. Berbeda dengan novel $P K J$, Penghadiran tokoh lakilaki dalam $R D P$ lebih menonjol, yaitu Kertareja (dukun ronggeng), Sakarya (sesepuh Dukuh Paruk), Rasus,
Marsusi, Bajus, Dower, Blengur, dan Santika.

Berikut adalah perbandingan
gagasan fenomena mengenai
perempuan yang berprofesi sebagai
penari. Pada kedua novel tersebut,
yaitu novel RDP menghadirkan penari
ronggeng (Srintil) sedangkan novel
PKJ menghadirkan geisha (Matsumi).
Selanjutnya terdapat persamaan gagasan yang lain, yaitu geisha dalam $P K J$ dan rongggeng dalam $R D P$ adalah perempuan yang mengalami subordinasi terhadap kekuasan lakilaki yang telah dikonstruksi secara sosial. Tokoh Srintil dalam RDP dan tokoh Matsumi dalam $P K J$ menjalani profesinya sebagai penari, sebagai perempuan penari yang bekerja di sektor publik, namun demikian mereka tetap berada di bawah kontrol laki-laki. Matsumi yang berprofesi sebagai geisha berada di bawah kontrol Hanada Shan (majikan) dan Shoso Kobayasi, sementara itu Srintil yang berprofesi sebagai ronggeng berada di bawah kontrol Kertareja (suami istri dukun ronggeng). 
Jurnal Ilmu Budaya, Vol. 18, No. 2 Februari Tahun 2022

Kontrol laki-laki terhadap perempuan yang berprofesi sebagai penari, yaitu geisha dalam $P K J$ dan ronggeng dalam $R D P$, merupakan kontrol terhadap aspek biologi. Dalam aspek biologis, penari dalam kedua novel tersebut terdapat gagasan "penghilangan" kodrat mutlak perempuan, yaitu bahwa penari (ronggeng dan geisha) tidak diperbolehkan menikah, dan tidak boleh hamil serta melahirkan. Kontrol ekonomi yang terdapat dalam kedua novel tersebut berupa harus dipenuhinya syarat mutlak bagi calon penari, yaitu mizuage (pelelangan keperawanan) bagi calon geisha dan bukak klambu (sayembara keperawanan) bagi calon ronggeng. Penari pada kedua novel tersebut memiliki tugas yang sama dalam profesinya, yaitu sebagai penghibur laki-laki, termasuk memberikan pelayanan seksual kepada laki-laki.

Selanjutnya, mengenai pandangan masyarakat. Geisha dalam $P K J$ dipandang memiliki status tinggi di Jepang, namun di luar jepang profesi geisha setara dengan pelacur. Demikian juga, ronggeng dalam $R D P$. Ronggeng dipandang sebagai citra perempuan ideal di Dukuh Paruk, namun di luar Dukuh Paruk, ronggeng dianggap tidak lebih dari sekedar perempuan penghibur/sundal.

\section{Daftar Pustaka}

Aziz, Sohaimi Abdul. 2001. Kesusteraan Bandingan. Selangor: Yeohprinco SDN BHD.

Basnett, Susan. 1999. Kesusasteraan Bandingan. Diterjemahkan dalam bahasa melayu oleh Shamsudin Jafaar. Kuala Lumpur: Dewan Bahasa dan Pustaka.

Bhasin, Kamla. 1996. Menggugat Patriarki: Pengantar tentang Persoalan Dominasi terhadap Kaum Perempuan. Diterjemahkan dalam bahasa Indonesia oleh Nug Katjasungkana.Yogyakarta:

Yayasan Bentang Budaya bekerjasama dengan Kalyanamitra.

Bhasin, Kamla dan Nighat Said Khan. 1993. Persoalan Pokok Mengenai Feminisme dan Relevansinya. Diterjemahkan dalam bahasa Indonesia oleh S. Herlinah. Jakarta: PT Gramedia 
Jurnal Ilmu Budaya, Vol. 18, No. 2 Februari Tahun 2022

Pustaka Utama bekerjasama dengan Kalyanamitra.

Clement, Robert J. 1978. Comparative Literature as Academic Disiplin. New York: The Modern Language Association of America.

Esten, Mursal. 1990. Kesusasteraan: Pengantar Teori dan Sejarah. Bandung: Angkasa.

Fakih, Mansour. 1996. Analisis Gender dan Transformasi Sosial. Yogyakarta: Pustaka Pelajar.
Fang, Lan. 2006. Perempuan Kembang Jepun. Jakarta: PT Gramedia Pustaka Utama.

Humm, Maggie. 1986. Feminist Criticism: Woman as Contemporary Critics. Brighton: Harvester Press.

Johnston, William. 2005. Geisha, Harlot, Strangler, Star: A Woman, Sex, and Moral Values In Modern Japan. West Sussex: Columbia University Press

Tohari, Ahmad. 2009. Ronggeng Dukuh Paruk. Jakarta: PT Gramedia pustaka Utama. 